\title{
PROCESSO FORMATIVO E PRÁTICO DO PALHAÇO
}

\author{
AUTOR: ALYSSON PERES DA SILVA \\ CO-AUTOR/ORIENTADOR: FABIO NIETO LOPEZ
}

Resumo: Este estudo de casos múltiplos pesquisou discursos e diferenças de compreensão sobre a formação e prática do palhaço a partir da perspectivas de agentes que realizam este trabalho no Hospital Manoel Novaes, em Itabuna, Bahia. Tendo em vista o aporte teórico desta pesquisa, a obra Razões Práticas, de Pierre Bourdieu, foram selecionados palhaços considerados diversos quanto ao campo de origem: um palhaço do campo artístico, um palhaço do campo religioso, e um palhaço híbrido - com experiência nos dois campos, mas com origem no campo religioso. A questão principal da pesquisa era compreender se diferenças de habitus e capitais, do campo religioso e do campo artístico, influenciam na compreensão, valorização, formação e prática do palhaço. Como resultado de nossa análise, compreendemos que há importantes diferenças entre os campos, e que os capitais são determinantes para a construção e propósito do ofício do palhaço, uma vez que no campo religioso o palhaço foi compreendido como um personagem que deve promover, através da risada, a compaixão. No campo artístico, o palhaço foi visto como um ser que coexiste com a pessoa que o representa, tendo suas próprias características e identidade, valoriza o emergente das situações, e considera que o riso não é o centro de sua prática, especialmente em um local de vulnerabilidade, como um hospital, dando lugar a outros elementos, como a imaginação, o jogo, a brincadeira, a empatia, o sonho. Com o palhaço híbrido encontramos uma situação marginal, no qual esses diferentes campos por vezes se encontram e, em outras, se distanciam na representação do palhaço. Concluímos, assim, que de acordo com o campo, as marcas do habitus e capitais marcam diferenças não somente na concepção de palhaço, mas também na sua formação e atuação. Compreendemos nossas limitações no desenvolvimento do estudo devido a diversos fatores externos, como por exemplo a pandemia, que nos impediu de realizar uma pesquisa enriquecida por observações das práticas. Diante da complexidade do tema, torna-se necessário aprofundamentos com novas pesquisas.

Palavras-chave: Palhaço, Campo, Capital, Religioso e Artístico. 